\title{
Glenda Tibe Bonifacio, Pinay on the Prairies: Filipino Women and Transnational Identities (Vancouver: University of British Columbia Press, 2014). 328 pp. \$34.95 Paperback.
}

Glenda Tibe Bonifacio's Pinay on the Prairies: Filipino Women and Transnational Identities (Vancouver: UBC Press, 2014) is a welcome addition to the literature on Filipina experiences in Canada and to the research on immigrant settlement and transnationalism. Instead of examining the traditional metropolitan centres in Canada, such as Toronto or Vancouver, this book draws our attention to Filipina experiences in Alberta, Saskatchewan, and Manitoba. Pinayism or Pinay peminism informs Bonifacio's research in studying the social incorporation of Filipino women by exploring the migration, identity, community, and civic engagement of Pinays in Western Canada. In doing so, Bonifacio effectively disrupts the common representation of Filipino women in the media and presents an alternative portrayal of Filipino women and the "many ways in which they make a difference, not only in their own lives but also in the lives of others" (21-22). This exploration sheds light on the agency and empowerment of Filipino women as they navigate their negotiated identities and community participation in their daily lives.

By specifically focusing on Filipino women's civic engagement in the Prairies, Bonifacio brings together the literature on Philippine political economy and Canadian immigrant settlement and transnational experience. Bonifacio weaves in the theme of how "being Filipino" is "identity becoming" beyond national borders - that distinct sense of who we are away from home" (2) for the women under the framework of Canadian multiculturalism. This gendered analysis is particularly unique because it is situated in the Canadian Prairies. For example, in 2006, Filipinos were the largest ethnic minority in Winnipeg, accounting for 34.6 per cent of the 64 per cent visible minorities in the province. ${ }^{1}$

Bonifacio conducted focus-group discussions and interviews with first generation Filipino women, permanent immigrants and temporary migrants from Alberta (Edmonton, Red Deer, Calgary, Pincher Creek, Picture Buttle, Lethbridge, and Cardston), Saskatchewan (Saskatoon and Regina) and Manitoba (Winnipeg). One of Bonifacio's goals in this research was to present a different segment of the Filipino population. Filipino women who are traditionally studied in the literature are from the Live-in Caregiver Program (LCP) in Canada and the aim was to present a different side of Filipino women who migrate to Canada (3). This project studies Filipino women of different migration status together. Bonifacio's sampling method was to identity female community leaders and a person fulfills this criterion by having one contact who had labeled that person as key community woman. By speaking to informed members of the community, Bonifacio fulfills her objective in representing a different segment of the popula- 
tion and meritoriously illustrates how they are actively involved in community participation and volunteerism. An alternative explanation to how the themes of migration, identity, and community building occur may present itself if a different strategy of recruitment was employed. For instance, what would have happened if ordinary people were involved as the participants; would their experiences and engagement with the community be similar or different?

Throughout the book, Bonifacio skillfully illustrates the negotiations of multiple identities Filipino or Filipino Canadian women engage in as they participate "both within and beyond their communities" (248). This research widens the lens of migration, settlement, and transnationalism in Canada and enriches the literature of Filipina experiences. As Bonifacio offers, studying dual citizenship is one area where future research can be extended (230). The meaning and reasons as to why people hold citizenship is particularly relevant because this category can potentially mobilize grassroots political activism and facilitate women's empowerment. As this research focuses on first generation Filipino women, future research can examine how subsequent generations, like the second generation of Filipino Canadian women, encounter identity, transnational practices, and incorporation. This analysis could further engage with the literature on intergenerational issues and transnational families. Bonifacio's research does illustrate the "collectivist orientation of Philippine society" (249) and the tight kinship system and social networks involved in maintaining and sustaining such linkages and ties. Moreover, as Bonifacio notes that Canada's multicultural landscape and policy shape the lives and experiences of these first generation Filipino women in Prairies, this raises important questions as to how the themes of migration, identity, and community building will look like in other countries. As this book is premised on showcasing the triumphant nature of migration and settlement for Filipino and Filipino Canadian women in Prairies, the potentially exploitative migrant worker program is not covered unlike her other work. In shifting the focus of the scholarship, Bonifacio's research gives another dimension to Filipino and Filipino Canadian women in Canada. Overall, this text opens up the dialogue into researching other avenues such as intergenerational family dynamics, transnational families, and international comparisons. Glenda Tibe Bonifacio's Pinay on the Prairies: Filipino Women and Transnational Identities deliveries an important contribution to the research on Filipina experiences in Canada and is an invaluable resource for graduate students and researchers studying Canadian migration, transnational identity, and community.

1 Manitoba Immigration and Multiculturalism. "Ethnicity Series: A Demographic Population of Manitoba. Volume 3: Population Groups and Ethnic Origins," https://www.gov.mb.ca/labour/immigration/pdf/manitoba-immigration-ethnicity-series-3.pdf

Mabel Ho

University of British Columbia 